\title{
Working of Ideology in the TV Commercials of Cold Drinks in Pakistani Media
}

\author{
Madiha Ahmad (Corresponding author) \\ University of Lahore (Sargodha Campus), Pakistan \\ E-mail: madihaahmad1991@gmail.com \\ Sofia Ahmad \\ University of Lahore (Sargodha Campus), Pakistan \\ E-mail: sofiaahmad0@gmail.com \\ Nida Ijaz \\ University of Lahore (Sargodha Campus), Pakistan \\ E-mail: nida_24capri@yahoo.com \\ Sumera Batool \\ University of Lahore (Sargodha Campus), Pakistan \\ E-mail: sumerabatool47@yahoo.com \\ Maratab Abid \\ University of Lahore (Sargodha Campus), Pakistan \\ E-mail: maratab_abid@yahoo.com
}

Doi:10.7575/aiac.alls.v.6n.2p.247

Received: 20/12/2014

URL: http://dx.doi.org/10.7575/aiac.alls.v.6n.2p. 247

Accepted: 24/02/2015

\begin{abstract}
The article aims at the analysis of the TV commercials of three carbonated cold drinks from Pakistani media. The analysis will be carried out using the three dimensional framework presented by Fairclough. Through the analysis, the ideological framing of the commercials will be brought to light. To achieve this purpose different techniques used by the ad- makers will be described, interpreted and explained in the light of critical discourse analysis.
\end{abstract}

Keywords: Advertisements, Power, Ideology, CDA, Fairclough

\section{Introduction}

While the issues of ideology, power, gender and identity are aimed at in various studies taking concrete instances usually from the printed advertisements of different products such as beauty products (Kaur, Arumugum, \& Yunus, 2013), and services such as that of airlines (Conradie, 2013), banks' advertisements (Tahmasbi \& Kalkhajeh, 2013), this study aims at the issue of ideology along with power taking its subject from TV commercials (henceforth TVCs). TVCs are an important form of advertisement being one of the major source of marketing in the present world due to their wide ranging scope through the media. Although there are other types of advertisements including both printed and electronic media as well, but due to the TVC's access to mass audience, these commercials gain wide reception. In order to lure the masses to seek the services or the products which are sold through these commercials, certain persuasive techniques and ideologies are employed in them. In this article these techniques will be explored through the analysis of selected commercials of three carbonated soft drinks from Pakistani media.

The objectives of the study are:

1. To describe the structure of the selected TVCs.

2. To find out the techniques used in the TVCs of cold drinks.

3. To discover the underlying themes of the selected TVCs.

4. To search for the impacts, expected by the ad- makers, on the viewers.

5. To look for the ideologies exploited in these TVCs.

2. Review of literature

\subsection{Advertisement}

An advertisement, in a broad sense refers to the practice of informing the people about some product or service and persuading them to buy or avail it. Cook (2001) rejects such function oriented definition of advertisement for three reasons. Firstly because there are some ads which do not aim at selling a product. Secondly, the function of persuasion can be achieved by any genre other than that of advertisement. Thirdly, the genre of advertisement might serve to perform several different functions besides the function of persuasion. For these reasons Cook suggests a prototypical approach, where advertisement will be defined in terms of some typical features or technique. 
Advertisements aim at constructing or changing our opinion or belief about something or some issue. For this purpose they make use of a number of techniques: they draw upon different genres and target upon specific population which is the focus of their product. Since every product is designed with certain type of users in mind, every commercial is orchestrated with some 'ideal audience' in mind (Fairclough, 1989).

Advertisements are identified as a separate genre, employing different types of strategies in order to persuade, inform, influence, warn, or even misinform or manipulate the audience to act in a certain way, i.e. to buy some product, to adapt to or avoid a certain life style or to vote for some political party (Cook, 2001).

The discourse of advertisements consists of the text of the ad along with the context in which the ad is produced and consumed. Van Dijk (2008) argues that contexts can be classified into different types and that 'these types are often related to different discourse genres'. The context of advertisements includes the following components.

1. Substance: the physical material which carriers or relays text

2. Music and pictures

3. Paralanguage: meaningful behavior accompanying language, such as voice quality, gestures, facial expressions and touch (in speech), and choice of typeface and letter sizes (in writing).

4. Situation: the properties and relations of objects and people in the vicinity of the texts, as perceived by the participants.

5. Co-text: text which precedes or follows that under analysis, and which participants judge to belong to the same discourse.

6. Intertext: texts which the participants perceive as belonging to other discourse, but which they associated with the text under construction, and which affects their interpretation.

7. Participants: their intentions and interpretations, knowledge and beliefs, attitudes, affiliations and feelings. Each participant is simultaneously a part of the context and an observer of it. Participants are usually described as senders and receivers (The sender of a message is not always the same as the addressers, however, the person who relays it. In a television ad, for example, the addresser may be an actor, though the sender is an advertising agency. Neither is the receiver always the addressee, the person for which it is intended. The addressees may be a specific target group, but the receiver is anyone who sees the ad.)

8. Function: what the text is intended to do by the senders and addressers, or perceived to do by the receivers and addresses (Cook, 2001, p. 4).

$2.2 C D A$

According to van Dijk (2008), "Critical discourse analysis (CDA) is a type of discourse analytical research that primarily studies the way social power abuse, dominance, and inequality are enacted, reproduced, and resisted by text and talk in the social and political context" (p. 85).

The main tenets of CDA (as cited in Van Dijk, 2008) are summarized by Fairclough and Wodak (1997).

1. CDA addresses social problems

2. Power relations are discursive

3. Discourse constitutes society and culture

4. Discourse does ideological work

5. Discourse is historical

6. The link between text and society is mediated

7. Discourse analysis is interpretative and explanatory

8. Discourse is a form of social action. (p. 86)

Discussing the origin of CDA, Wodak (2001) confers that a form of discourse and text analysis began to emerge in the 1970s to be known as Critical Linguistics, which identified and focused on the relation between language and social status and power attribution. Since the 1990s, the term CDA is being preferred instead of CL for this approach. However, Fairclough (1995) has raised some issues lacking in the practices of CL, and argues that CDA is an extended and developed form of CL. In general Fairclough's Language and Power published in 1989 is considered a major breakthrough for the beginning of CDA (Blommaert, 2005).

The notion of critical in CDA, according to Fairclough, Mulderrig and Wodak (2011), indicates CDA's role in "explaining social phenomena and (...) changing them" (p. 358).

CDA is neither in any way a single theory or methodology nor can it be approached by a specific theory or methodology. The subject matter or purpose of CDA is to discover and explore the relation between discourse and power and the degree of this relationship. To achieve this purpose CDA originates its theories and methodologies from a number of theories with different methodologies. According to Wodak (2001) the most well-known areas of study under CDA are issues of gender and racism, political and media discourses. Different researchers adopt different theories and methodologies according to their area of study.

CDA is an interdisciplinary approach which draws its theories and methodologies from different disciplines. It involves teamwork by the researchers belonging to different disciplines. These researchers approach the issue from various perspectives and only those theories, methodologies and tools are made use of which properly address and explains the problem. The hypothesis is inferred from the observations and is constantly improved and revised according to the results of the study in order to avoid 'fitting the data to illustrate a theory'.

In order to identify how texts from different social settings are brought together and outside references are incorporated, CDA explores and studies multiple genres. Historical context is also consulted in order to identify the 'change', intertextuality and interdiscursivity in the given text and discourse. Different grammatical theories are used in different approaches of CDA but mostly Systemic Functional Linguistics is exploited. In order to bridge the gaps middle ranged 
theories are favored in CDA. The main aim behind CDA is to practically apply the findings on the discursive practices (Chouliaraki \& Fairclough, 1999; Fairclough, 1995; Van Dijk, 2008; Wodak, 2001).

No matter what the area of investigation is, the concepts of power, ideology, discourse, hierarchy and gender are central to $\mathrm{CDA}$ in the interpretation and explanation of the text.

\subsection{Discourse, power and ideology}

In the domain of CDA discourse is referred to as 'social practice' of language, written and spoken (Fairclough \& Wodak, 1997) where the context in which language is used is decisive. This means that not only it is that discourse influences the social context but it works other way round too. The social context affects the discourse too. Social context involves the variables such as the relationship between the speakers, their social roles and situations. Since social context is conducive to discourse, it (discourse) carries the crucial issues of power and ideology with it (Fairclough \& Wodak, 1997).

The notion of power and social power of groups and institution is central to the critical study of discourse. A group or institution produces and exercises its social power through discourse by controlling the thoughts and actions of the people (van Dijk, 2008). The access to the media and to the discourse of media is one of the important criterion for exercising the power as any group with more access to the means of production is in the powerful position of controlling the text and the context of the discourse and subsequently the minds and then actions of the people according to its agenda or motive.

Thus the power is practiced and enacted in media through different strategies including persuasion, dissimulation and manipulation (Fairclough, 1989). The people consider the powerful group more informed and dependable and take the discourse from them as an authority to construct their beliefs and opinions on the state of affairs. This form of power and domination is hegemonic as it is imposed by the consent of the people. This consent is manufactured through naturalizing the practices in a way that they look commonsensical and natural (Fairclough \& Chouliaraki 1999).

Relying on the concept of ideology and hegemony by Marx, Engel and Gramsci, Fairclough (1989), van Dijk (1998) and Fowler (1991) emphasize the role of Ideology in manufacturing consent in order to make a state of affair, an opinion or a belief seem natural or common sensical. Ideology works in such a way that people act in a certain way without actually being aware of it, or at least the motive behind it. According to Thompson the study of ideology is a study of 'the ways in which meaning is constructed and conveyed by symbolic forms of various kinds' (as cited in Wodak \& Meyer, 2002, p. 10).

Thus ideology has a crucial role in the establishment and maintenance of power relations and consent through discourse.

\section{Methodology and theoretical framework}

The study involves the analysis of three commercials of cold drinks from the Pakistani electronic media. Three commercials that of Coca Cola, Sprite and Mountain Dew will be analyzed with the focus on the multimodality aspects i.e. "....... The combination of words with other modalities, such as pictures, film or video images and sound" (Paltridge, 2008, p. 189).

The analysis will be done using three dimensional framework of Fairclough, which aims at highlighting the processes of the production of the text, its interpretation by the participants and the social conditions in which this production and interpretation takes place (Fairclough, 1989).

The framework includes three dimensions of the discourse; text, discourse practice and sociocultural practices. These dimension correspond three stages of critical discourse analysis namely description, interpretation and explanation.

The description stage is "concerned with the formal properties of the text" (p. 26). The interpretation stage deals with the "cognitive process of the participants" (p. 27). The explanation stage is concerned with the social conditions in which the texts are produced and interpreted.

The division between the dimensions of discourse and critical discourse analysis is clearly shown in figure 1 which demonstrates the interrelation between these dimensions.

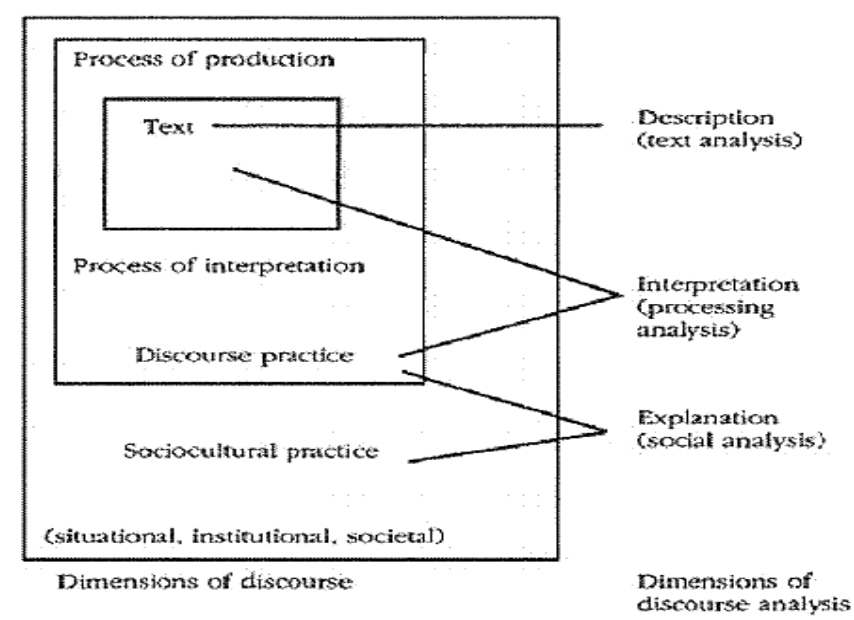

Figure 1. Fairclough's dimensions of discourse and discourse analysis. (From Locke, 2004, p. 42) 
4. Analysis and finding

\subsection{Text Analysis}

At this level of analysis, the linguistic features of the text, which comprise of the transcription of the spoken dialogues, will be examined. The multimodality features will also be discussed in terms of the voice over and the visuals.

Voice over is an important feature of commercials, as they can be used to give a clear message with in less than 60 seconds. The commercial of Coca Cola uses the female voice over. The voice is presumably of the woman character in the ad and not of someone outside it. The woman is telling the importance of eating together in soft and gentle, but suggestive tone which suggests the speech of a care taker and instructor.

In the ad of Sprite, the voice over is a song in a female voice. The song is very loud, energetic and fast. It is about spicy food and supplementing it with sprite. The chorus of the song is specifically about intensifying the spice with sprite. Most of the lyrics of the song are imperative.

The voice over in the dew ad is included only in the end where a male voice says 'dew na kia to phir kya jiya' in a challenging tone.

Another important feature of the commercials is the use of imperatives. All three ads end up in the imperative statements either in voice over or in written message

$>$ Chalo sath khaen ('Let's eat together')

$>$ Sprite, mann ki maan ('Sprite, obey your thirst')

$>$ Dew na kia, to phir kya Jiya ('Do the Dew')

These statements are the main themes of the situations shown in the ads and also the slogan of the relative cold drink companies. The slogan of the Coca Cola ad is suggestive, as indicated by the word 'Let's'. Let's is the contracted form of 'let us', which creates a bond between the addressor and the addressee, so an attempt has been made to create a relationship between the product and the viewers. In the catchphrase of the Sprite ad there can be felt an empty slot before "Sprite, obey your thirst", which is most likely to be filled with 'choose'. Now here it can be seen that the sprite is associated with the natural choice to quench your thirst and a directive tone is used, as indicated by the word 'obey'. The slogan of the Mountain Dew ad is also directive as it simply tells just to do the dew, leaving nothing on the viewers' part.

The attire of the characters in the ads is also an important feature since the lead characters are wearing the dresses in accordance with the color combination of the product, for example the female character in the Coca Cola ad is dressed in red while the lead characters in the Sprite and Mountain Dew ads are wearing green in accordance with the color of their brand. Another notable point is the red t- shirt of the other boy in the Mountain Dew ad. Usually red is the color associated with action and thrill but the boy in red is shown timid. The red color might have been used to point towards other energy drinks using red color in their logo and product, thus a contrast is hinted at just by the use of color in the attire.

In order to make the slogans catchy and memorable, alliteration is used such as in:

\section{$>$ Mann ki maan}

\section{$>$ Do the Dew}

\subsection{Discourse Practice}

This section will discuss the processes related with interpretation and interaction between the text and the receiver in terms of finding out the target audience and how they are framed, that is, "the way in which the content of the text is presented to its audience, and the sort of the perspective, angle and the slant the writer or speaker is taking" (Paltridge, 2008, p. 187).

The ad of the Coca Cola mainly targets the females as its audience. Though it is not restricted that the consumers are to be females only as the whole family is shown consuming the product in the ad. However, the fact that is exploited is that usually it is considered the duty of a woman to manage the house hold affairs, cook food and keep the family happy, healthy and together, also it is assumed that a good wife and mother will take special care of the fact that her family takes in healthy and nutritious diet. The woman in the ad is shown as a perfect woman fulfilling her above mentioned duties. While the voice over which is apparently hers, is suggesting the audience to eat together, the woman is shown pouring Coca Cola in the glasses of the family members. When her husband gets busy with phone, she takes it from his hand with a reprimanding expression and hands him over the glass of Coke. So the woman is shown as an authority in her home who is keeping her family members together, thus she is made the authority for the audience as well who can suggest the house wives that they should do the same. In this way she is persuading the target audience to act in a certain way. The ideology is worked in by 'fusing' the product with values which are cherished by people.

The ad of Sprite is targeted towards the foodie people who love eating out. The ad shows sprite bringing strangers together in a literally healthy competition as it involves food.

The ad of Dew is targeted at the adventurous male youth who like to engage in extreme and daring sports. The ad does not have any female character in it. The lead character engages himself in a dangerous stunt after "doing the Dew" and does not show a slightest hint of fear. Thus the ad promotes the idea that Mountain Dew eliminates fear and makes you tough enough to overcome any dangerous situation.

\subsection{Social Practice}

The social conditions which govern the process of production and consumption of the text are a main concern in this phase of analysis. In this part the larger picture will be looked at.

The ad of Coca Cola is a part of a bigger world-wide campaign, Let's Eat Together, creating emotional appeals in order to bring people together and communicate the feelings of happiness and joy. They are appealing to the values which are 
cherished by people and fusing their product with these values and moments of joy and happiness in such a way that one looks incomplete without the other.

The ad of Sprite also comes from the series of ads linked with spicy food and eating out. Thus the target market of Sprite are the food streets or food spots. The product is repeatedly associated with the spicy food, thus reinforcing the message they want to communicate to the masses i.e. whenever you go out to eat, your natural choice should be Sprite. Now here it should be kept in mind that Coca Cola and Sprite are the products of the Coca Cola Company, so it can be clearly seen how the company has targeted its products for different situations rather than the specific audience, i.e. when you want to enjoy with your family, the natural choice would be Coca cola and when you are out for food and mingling up with strangers, the preferred choice is Sprite.

On the other hand the ad of Mountain Dew which also comes as a piece of a larger picture, locates the male youth as its target market, since all the Dew ads feature only male characters, who are indulged in thrilling and adventurous sports, such as skateboarding, horse riding, base jumping, cycling etc. They show the Mountain Dew as a part of extreme sports culture. All the ads of Dew depict the situation in which either the Dew guys are risking their lives for Dew or are performing life- threatening stunts after drinking it, conveying the message that Dew boosts up your energy level and eliminates the fear so much so you stop at nothing. Thus the ad appeals to the daring and adventurous side of the male youth.

\section{Conclusion}

Through the present analysis of few selected commercials an attempt has been made to demonstrate how these discourses work at different levels of ideology to persuade and appeal the public into buying the products and how a large community of devoted consumers is formed on the basis of these ideologies and social values which these commercials tend to construct or reiterate by association. The analysis also helps to reveal how the commodities are fetishized for the purpose of wide-ranging consumerism. The products are shown as containing some magical powers that can bring people together and make them happier or fearless. Thus aspects which are highly valued by people, such as being together or being fearless or being social, are exploited in order to make them buy the products.

\section{References}

Blommaert, J. (2005). Discourse: Key topics in Sociolinguistics. New York: Cambridge.

Chouliaraki, L. \& Fairclough, N. (1999). Rethinking Critical Discourse Analysis. Edinburgh: Edinburgh University Press.

Conradie, M. (2013). A critical discourse analysis of race and gender in advertisements in the South African in-flight magazine Indwe. African Identities, 11(1), 3-18. Retrieved from Research Gate.

Cook, G. (2001). The discourse of advertising. London: Routledge.

Dijk, T. (2008). Discourse and power. Houndmills, Basingstoke, Hampshire: Palgrave Macmillan.

Dijk, T. (2008). Discourse and context: A sociocognitive approach. New York: Cambridge.

Fairclough, N. (1989). Language and power. London: Longman.

Fairclough, N. (1995). Critical discourse analysis: The critical study of language. London: Longman.

Fairclough, N. L. and Wodak, R. (1997). Critical discourse analysis. In T. A. van Dijk (Ed.), Discourse Studies. A Multidisciplinary Introduction, Vol. 2. Discourse as Social Interaction. London: Sage

Fairclough, N., Mulderrig, J., \& Wodak, R. (2011). Critical Discourse Analysis. In T. Dijk (Ed.), Discourse studies (2nd ed., Vol. 2, p. 358). Los Angeles: SAGE Publications.

Fowler, R. (1991). Language in the News: Discourse and ideology in the press. London: Routledge.

Kaur, K., Arumugam, N., \& Yunus, N. (2013). Beauty Product Advertisements: A Critical Discourse Analysis. Asian Social Science, 9(3), 61-71. Retrieved from www.ccsenet.org/ass

Locke, T. (2004). Critical discourse analysis (p. 42). London: Continuum.

Paltridge, B. (2008). Discourse analysis: An introduction. London: Continuum.

Tahmasbi, S., \& Kalkhajeh, S. (n.d.). Critical Discourse Analysis: Iranian Banks Advertisements. Asian Economic and Financial Review, 3(1), 124-145. Retrieved from http://aessweb.com/journal-detail.php?id=5002

Wodak, R. (1997). Gender and discourse. London: Sage Publications.

Wodak, R. (2001). What CDA is about - a summary of its history, important concepts and its developments. In M. Meyer \& R. Wodak (Eds.), Methods of critical discourse analysis. London: SAGE. 


\section{Appendices}

\section{Appendix 1: Ad of Coca Cola ${ }^{\circledR}$}

(The ad opens with red background with water droplets and with "Coca Cola ${ }_{\mathrm{R}}$ " written on it in its typical style)

The first scene opens in the dining room where four people (i.e. an old man, a young man, a boy and a girl) are sitting on the dining table for dinner.

The meal is already served on the dining table but nobody has started yet.

The old man is narrating some story making a lot of gestures and other three members are listening to him cheerfully. The boy and the girl have smile on their face.

A woman appears getting hold of a 1.5 liter coca cola from the cabinet, probably.

The woman enters the dining room with eyes on the old man (who is still telling the story), a smile on her face and uncovering the bottle all at the same time.

The woman pours the soft drink in the glass of her son, firstly.
Music starts from the very first second of the ad and continues till the end.

Audio from the visuals are muted. A voice over of a woman runs throughout with a soft music in the background.

"Roz khana sath khanay mn,"

"Kai aesi baton ka bhi

ehsas hota hai,

jinki ehmiyat shaid kahin

kho gai hai."

'In dining together daily, we realize many certain things whose importance has been faded away somewhere' 
The woman keeps on pouring the coca cola in the other glasses as well while the old man continues narrating the story, making the two children smile.

The young man gets busy with the cell phone and apparently, his attention diverts from the old man's story towards his phone.

The old man feels that diversion of the attention so, he instantly keeps quiet.

The woman, while still pouring the soft drink in the glass, looks at the old man and takes the cell phone from the man and semiotically makes him realize about the ignorance he has just made towards the old man's story.

The man, through his facial expressions, shows his guilt.

The woman asks the old man:

The old man smiles and winks at the woman.

The man gently presses the hand of the lady in
Music...

“Jaesy Dada jan or unkay wohi qis'say, *(liquid pouring sound from the real- time visual) jinhen wo her roz utnay he piyaar se is liye sunatay hain, takay hum unki mojudgi ko mehsoos kar saken" (liquid pouring sound)

'Like Grand pa and his those very narrations, which he narrates daily with the same affection, so that we can feel his presence,

“Qadar tab ati hai unki baton ki, jab wo achanak...(a little pause)...chup hu jaen

(liquid pouring sound)

'The value of his talks is realized only when he suddenly ...(a little pause)... becomes silent'

Music....

[(audio from the real- time visual) “phir kiya hua, abba?”] 
thanking manner.

All the members smile and laugh and take their meal

"kiun na ye ehsas roz jagaen”

while the young man drinks the coke.

'Why not make this feel arise everyday'

"Chalo sath khaen"

[(audio from real- time visual)

Laughters...]

'Let's eat together'

And a red colored bottle of coke appears on the white back ground along with words written:

"Chalo sath khaen"

'Let's eat together'

"Khulien khushian”

'Happiness rejoiced'

Music....

Appendix 2: Ad of Sprite

The ad begins with the green back ground having written

The ad begins with the thrilling music.

"Sprite ${ }_{\mathrm{R}}$ " in white color.

The first scene opens in a food street where vegetables

like capsicum, lemons and green chilies are hung on both sides of the street and hash slingers are busy in cutting vegetables and cooking. A guy runs with his back towards the camera.

Various food items e.g. bar.b.q, taka-tak etc. are shown.

A hand squeezes lemon. 
A hand holding the bottle of sprite removes the water droplets with the thumb.

The guy meets his friend who was already siting on a table wearing green shirt.

Another guy is holding a crate of sprite in which there is only one sprite left. The first guy calls him and asks him to hand him over that one sprite.

In the meanwhile, a girl, sitting with her friends on another nearby table wearing printed shirt with green background and white print on it, calls the guy holding crate to hand her over that sprite bottle.

The first guy gives a look towards her.

The guy with the crate walks towards the girl instead of the first guy.

The first guy keeps his eyes on the sprite and finally gets that sprite instantly while the guy with the crate keeps on moving.

The girl looks at the guy with a surprising note positioning her hand towards him.

The guy calls the nearby hash slinger who is a healthy man in front of whom green chilies and onions are hung and asks him:
The song begins after the first five seconds of the ad and the vocalist is a female.

"Macha ly shor"

'Bring it on'

"Bottle khol"

'open the bottle [of sprite]'

"Chickh chickh na kar tu”

'Shut it up'

\section{"Munn ki bol”}

'Obey your heart' 
The hash slinger nodes his head in a positive manner.

In the meanwhile the girl asks the same hash slinger:

The hash slinger looks at the girl surprisingly.

A hand sprinkles extra spices on the fricassee which is on high flame.

A hand sprinkles chopped green chilies on the fricassee.

The same hash slinger serves the ready fricassee on the girl's table and the guy's table respectively.

[(audio from the real- time visual)

“Chacha...Mirchi taiz”]

'hey, Make it spicy!'

The guy looks at the girl with raised eyebrow.

The girl semiotically challenges the guy to eat that double spiced fricassee.

She stands and pushes the table to join with the guy's

"Chacha...Mirchi double taiz" table.

On the other hand, the guy also pushes his table and joins the two.

'Hey, make it double spicy!' 
The girl rotates the bottle to toss that whose fricassee would be eaten and gives a tough look to the guy.

The girl wins the toss and the guy look at her with "oh no!" expressions.

The two take the morsels of chapatti and eat along with a small amount of fricassee with double spice.

The guy feels the spice therefore, water comes in his eyes.

Green chilies are thrown over the spices and sprite liquid moves in a circular motion.

Both, the girl and the guy drink sprite.

The girl looks at the guy with a sudden raise of the eyebrow as if saying "want more fun?" while the guy still drinks sprite while his friend shows frightening facial expressions.

Then they are served with the bar.b.q along with the green and red sauces.

The guy's forehead sweats while the girl and her friend feels comfortable with the spice.

The guy makes the face which shows the height of spice
“Bharka dey....bharka dey... bharka dey....Saiy'yan Sprite se"

'Intensify that hit of spice with Sprite'

"Haan....Macha ley shor...Bottle khol"

'Bring it on.... Open the bottle [of Sprite]'

"Chickh chickh na kar tu...man ki bol"

'shut up and obey your heart' 
in their meal while the girls drink sprite smoothly.

The guy has water in his eyes and he wipes his nose with his finger.

The girl passes a weeping gesture towards the guy mockingly.

The hash slinger also shows a sorry expression.

The guy gives up by raising his hands and the girl passes a victorious smile.

The girl puts the bottle on the table with force which makes the drink droplets rush out of the bottle.

Then the following words appear:

$$
\begin{gathered}
\text { "Mirchi ka tarka } \\
\text { Sprite } \\
\text { Se bharka" } \\
\text { 'Seasoning of spice } \\
\text { Intensified with } \\
\text { Sprite' }
\end{gathered}
$$

At the end of the ad, the words appear on a greyish lined background as:
"Mirchi ka rola height pe"

'The spice off is at its peak'

“Bharka dey....bharka dey....bharka dey.... Saiy'yan sprite se"

'Intensify that hit of spice with sprite'

"Han bharka dey saiy'yan Sprite se"

'Intensify that hit of spice with Sprite' 


\section{Appendix 3: Ad of Mountain Dew}

The ad begins by showing up a skate board imprinted with the specific logo Mountain dew, accompanied with the leg jerking by one of the two friends standing at the edge of a tremendous dam.

a guy wearing a green top, sipping Dew with some adventure going on in his mind

Whereas his fellow, wearing a red shirt, is extremely terrified when he sees the depth of $300 \mathrm{ft}$., tries to awaken his friend that it could be their goodbye to life.

But DEW boy looks down and in a care free manner says: (fluttering sound of flags)

"yaar ye to ta ta bye bye he"

'dude, it's like a final good bye'

"Kiun...Mujhy to 3 ft. he dikh raha hai"

'why? it appears to be only $3 f t$ to me' 
His friend says:

The next scene starts with the hovering of a helicopter and an expeditious slide made by the Dew guy from the edge of dam on his skateboard, leaving the crew behind him fully astonished.

Next comes the rapid down rush of water which follows the guy as he slides on the walls of dam...apparently he gets aware when he looks back at the gush of water that is chasing him so intentionally he jumps off the skateboard and dives into water.

Few seconds later, he shows up on the surface of water by waving dew skateboard.

The crew waiting on the edge is filled with high joyful energy and a red shirt boy passionately uplifts his friend who eagerly rushes to the top after a successful thrill.

Ad reaches its climax when the dew guy shows up a bottle of dew saying:

scene closes with the laughter and whistles heard in the background followed by the voice

the advertisements ends with the appearance of tagline DO THE DEW painted on the dam walls and logo of MOUNTAIN DEW appears on the screen
“Yeh...?? Abey, 300 ft. hai..... kia tujhy dar war nai lagra?"

'this?? man!. Its $300 \mathrm{ft}$...aren 't u even scared?'

$$
\text { (End of dialogues) }
$$

( very low sound of hovering of helicopter in air followed by some thrilling and adventurous music)

Sound of rushing water is also added in the scenario.

Music pauses after a loud sound of splash when boy jumps into the water.

music continues again with the rock gesture made by the guy and his voice is heard as “yaaaaaaaayyyyyyyyyyyy...”

(Joyous laughter and whistling of the crowd)

“Dew kar jaa ...ya ghar ja”

'DO THE DEW..OR...

$$
\text { EXIT THE VIEW }
$$

commercial ends with the voice of man saying followed by the slight thrilling music

$$
\text { “Dew na kia.... To phir kia jiya” }
$$

\section{'Haven't lived. If}

haven 't done the dew' 